\title{
Corpse eating and an illicit cult
}

\author{
Lambert Marani
}

The child's body was buried. But what I found curious was that the grave was not as deep as usual. Three days later, my curiosity was answered. These inland people dug up the grave again, retrieved the body, cut it up and then brought it into the forest. In the woods they cooked some of the flesh and ate it with leaves. Other flesh was wrapped with goraka (ginger root), bark and leaves, then discarded in another village.

Apparently this was a ritual which, according to local beliefs, could conjure a suangi (evil ghost). The intention of dumping the remaining pieces of the corpse in the other village was to get the suangi to kill the people of that village. This incident took place in kampung Boven-Tor, in Sarmi sub-division. As head of the district, I was angered to see all this. It was an act against God. I told the police to arrest those people, then I beat them with a rattan cane until the cane fell apart.

I then sent a single side band radio message to the HPB of Sarmi, Eduard van Voskuylen, whereupon he sent two Johnson motorboats and took the people to Sarmi to be put on trial. Those who received light sentences stayed in Sarmi; those who received heavy sentences were brought to Hollandia to serve their time there.

That was one of the interesting experiences I had while serving as a civil servant in the Papuan hinterlands after graduating from OSIBA. Another interesting experience was when I encountered a community that followed the kasiep sect, an illicit cult from Ormu that later spread to Genyem, Nimboran and Unurum. In this cult they sometimes swapped wives with each other. At the time I was serving as the district head of Unurum.

One morning around five, the whole village was dead quiet. I wondered what was going on. Why was the village so quiet? Where were the villagers? Another morning, because my house was by the roadside, 
I heard the voices of people walking. 'Where were they going?' I wondered. I became curious to find out more.

The next morning I stood guard again, and when I heard the voices I looked out and saw men and women walking in a certain direction. I followed them. It turned out they were going somewhere and swapping wives with one another. I then went to see the ondoafi (traditional leader) and asked him for an explanation.

As an important person in the village, the ondoafi would be sure to know what it was about. The ondoafi - who was handicapped, so that when he walked he had to be supported by both arms - then told me everything. To express my thanks I later gave him some contact goods - such as machetes, axes, trousers, cloth, and blankets. These materials had indeed been provided by the government to the administrators to facilitate relations with the communities in the interior.

After that I composed a letter and sent a messenger to bring it to the HPB in Genyem. I told the messenger: 'Wait until the police from Base $\mathrm{G}$ arrive in Genyem, only then will you leave to come here together'. The police (mobile brigade) came and they were all brought to Genyem. Those who received heavy sentences were then brought to Hollandia, while the ones with light sentences stayed in Genyem.

The followers of the kasiep sect did not worship the gods or praise the Lord. Nor did they sing and beat drums or gongs to worship God. They stole into houses quietly because they had evil intentions. The sect could enter and flourish in the interior because the people of the interior imitated their relatives who lived on the coast. When people from Genyem went to see family members who lived in Hollandia, or people from Ormu met family members in Sentani, they heard or were told about the sect. On returning home to their villages in the interior they did it there. These things were forbidden by the government because they were crimes. But the good habits of the community were still permitted.

HAPPY TO BE A GIVIL SERVANT

My decision to become a bestuursambtenaar (employee of the civil service) was based on none other than my desire to know the cultures and ways of life of the Papuan nation, both on the coasts and in the mountains 
in the interior. And because it would be possible for me to develop the people to make them good; to turn primitive people into a group capable of implementing government in Papua.

I was placed in the Hollandia interior, that is, the area of GenyemNimboran. The first thing we did as civil servants pertained to the cleanliness of the community. They had to learn to take care of their health, and see that the development of the villages was in their own interests. We developed them and by and by it appeared that those who once led primitive lives became human beings who could live well. That was the purpose of what we did. And to this day, the district of Unurum that I formerly managed has been good. They have come out of the forests into the villages.

Following a government decree, I was transferred from Hollandia to Unurum district. When I began doing my job there, I had to mingle a lot with the community. And I often visited the villages to get to know the people well and develop them to make good villages, good housing, and good lives. Eventually they recognized that their former lives were not good, and their new lives were better. In the end they wanted to follow the guidance we gave them.

They lived well. They no longer made war. They were not hostile to government officials in the district. There were no police there, only me acting as an administrator. But I could develop the community well, so that tribal warfare has not recurred to this day. From the time of the Dutch government to this day there have been no tribal wars, there have been no hostilities.

From Unurum district I was transferred to Nimboran to serve as the district head of Nimboran. While I was posted in Nimboran, all the communities were well behaved since they had been developed for a long time. The first HPB there was W.J.H. Kouwenhoven. He was the first person to open up Nimboran. During the time I served there from 1958 to 1961, I went all around Nimboran as far as Kemtuk Gressi. The people lived well. There were no wars because they were were frank with one another. Whatever they felt, they discussed openly. When problems arose, they were always settled according to adat law with the village heads. 
When I was transferred to Boven-Tor district (in Sarmi) the incident of the murder of the HPB and engineer, Andreas Hilkemeijer and two police officers took place in Unurum district. ${ }^{1}$ These murders were caused by the actions of the chief of police, who had burnt down the residents' houses. The chief of police had ordered the community and two policemen to burn down the houses because, according to them, the houses were unsightly and damaged. The inhabitants became angry.

After burning down the locals' houses, they headed for Urmerem to overnight there. The angry residents made a plan to get revenge. They waited on the road. HPB Hilkemeijer ordered the porters to walk ahead while he and the two policemen followed behind. The villagers intercepted and then slaughtered first, the policemen and then, the HPB, who was stabbed from behind. That was the sequence of events.

As long as I had been working there, nothing like that had ever happened before. I did what I could, working together with the community to dismantle the houses and build new ones. Yes, using our own ideas and available resources we were able to develop the community. We improved the cleanliness of the villages. When public health was disrupted, I went down to Genyem to fetch a doctor and we went into the forests to help people, Dr. Romijn and Dr. Kranendonk among others. It was the duty of the Health Department to assist with public health. It was my job while I served in Unurum. So from the time I began working in Unurum until I moved to Nimboran, the community was in good condition. No one was hostile towards me. There was no inter-village warfare. It was all good. And during the time I served in Unurum, I was instructed to build an airfield in Lereh, which has been used from the Dutch period until the Indonesian period today.

Those who helped with the construction of the airfield were the people of the interior themselves. The simple tools sent by the government, such as hoes, shovels, carrying poles, axes, and cross-cut saws, were air-dropped by plane because the aircraft could not really land yet.

The people there worked, and I paid them every two weeks. I had been given funds to build the airfield. And I was also instructed to open a government store. Goods for the store store were dropped by airplane.

1 Compare this (hearsay) version of the story told in greater depth and detail by Boekorsjom in Chapter 1 of this volume. 
The people received their money and then shopped at the store. I opened the store after work hours, and in the evenings they came with their money to shop. So I received the money back, and every two weeks I sent the money, which was picked up by helicopter, to the Department of Home Affairs, or DBZ. Then I went down to the city to shop. The people worked without the use of modern equipment. They were divided into two groups, one that worked from six in the morning until two in the afternoon, and another that worked from two in the afternoon until six in the evening. There was no heavy equipment like a bulldozer. The airfield is still in use today.

\section{GOSPEL TEACHERS}

During the time I was in charge there were no schools there. There were only gospel teachers who preached God's commandments. The people knew the alphabet because it was taught by these preachers. And we helped them with carpentry materials such as saws, planes, and nails to make boards. The gospel teachers did not open schools but gathered the children they could gather together, then taught them in the teachers' homes.

From the time I was posted there until I was transferred to Nimboran there were still no schools yet. While on duty in Nimboran, I wandered over to the district of Kemtuk Gressi. That all went well. The HPBs who served there during that time were Mr. Kees Lagerberg, Mr. Max Lapré, Dr. Pim Schoorl, Mr. Jaap Thooft and finally, Andreas Hilkemeijer. He was the last one I knew, because after that I was transferred to Sentani.

Every Sunday everyone went to church. Compassionate ways of living began to appear while I was there. When people killed a pig, or harvested a garden, they shared it to eat together. In Nimboran there were two churches, namely, GKI (the Indonesian Christian Church) and the Pentacostal Church. And there were churches in Tor, namely, GKI and the Adventist Church. There were no religions aside from that.

In Papua, from the beginning up to now, there have never been any inter-religious quarrels. At that time, a sense of unity was already visible among GKI and the Pentacostal, Catholic and Adventist churches, except for the Jehova's Witnesses, who were stigmatized and forbidden by the government. Everything was fine among the others. Mail deliv- 
ery to the villages was the responsibility of the Binnenlands Bestuur, in this case, the postbeambte (postman). He received the mail and waited for messengers from the district or sub-district who came to pick it up and distribute the letters without payment. The messengers from the HPB or the district office were responsible. The ones who took care of all this were the civil servants. They distributed all the letters to the respective addresses. Deliveries were made on foot, without vehicles.

Meanwhile, the health services provided by paramedics in Dutch times made the people happier. They were all the more welcome because they were so faithful in performing their duties. Yes, faithful! They came around every month. They were sent by a sub-division hospital, such as the one in Genyem. From the hospital in Genyem the paramedic made the rounds of the existing villages in the district. He walked around and if he saw someone who was sick, he served the person by giving the person an injection or medicine. The same was true in Unurum district. So they acted without orders, because they had a schedule to follow: on such and such a date they had to go. They did not use a plane, or a car, but travelled on foot.

The medicines were carried by hired people. The paramedic received toerneegeld (patrol money) that he had to pay the medicine bearers. The paramedic paid them upon completing the patrol and returning to Genyem. 'This is your due', he would say. These fees made people glad to follow the patrol. No one ever claimed the wage was too low and asked for a raise. The wage that was given was in accordance with the going rates. There was enough food to cook and eat. If they wanted to drink tea, there was tea and sugar; they could just make some and drink it. So if we wanted to go, the locals were happy because we served them well. We bought tobacco and cigarettes for them so they would be happy.

When rural people went to give birth in the forest, it was hard to find them. If they came to give birth at the hospital, they were served. But the ones in the forest were served by old women with experience in the villages. Nowadays the term used is traditional birth attendants, or midwives. They were not educated, they were not nurses, but they had the experience to help people.

Each district was generally served by only one paramedic. Whereas in the case of the midwives, as far as I know, in Genyem there were only two midwives. The midwives did not circulate to the villages, only the 
paramedics. In Unurum there was a paramedic; he walked on foot to visit the villages.

I made two- and three-week patrols; there were enough provisions for two or three weeks. My things were carried by porters, and they were paid. I had to pay them because I had received travel expense money.

\section{GUIDING PILOTS BY SSB}

To assist pilots in landing aircraft in the outback, we followed instructions from the Air Transportation Office in Hollandia. We had to observe the field situation. The best directions for the field to be positioned in were north-south or east-west. That was good because we had been given a compass. We looked at the sky. The patrols usually brought along a compass to confirm that north was here, south there, west there, and which way was east. You had to avoid making an airfield that complicated the landing of an aircraft, flanked by mountains here, mountains there. How could a plane hope to land? It had to be figured out properly!

To create an airfield, trees were not felled, but people had to dig up the ground and cut out all the roots in the earth, so the trees would be uprooted on their own. Only after that were the trees sawed. Giant trees were similarly dug up and their roots cut. Since there was no bulldozer, all the roots were dug up and cut, so the weight of the tree with all its branches and leaves would topple it. This was easier than felling the trees, and digging up their roots afterwards.

If a plane was to come in, there had to be news in advance through a single sideband (SSB) transmitter. From the SSB, which was a portable radio, we knew an aircraft was coming. The SSB ran on storage batteries. In the mornings the battery was run and the SSB turned on to catch news from Sentani about incoming airplanes. Once we knew, we would speak to the pilot: 'What time do you fly? If it's at such and such a time, then fly in from this side with a view to the direction of the wind and clouds.'

\section{CIVIL REGISTRY}

As district head I was also appointed to serve as 'extraordinary registrar'. That was one of the district head's responsibilities. If someone wanted 
to get married, we had to register it first. After registration, we had to wait. An announcement had to be made up to three times at the church, lest the woman was already engaged to someone else. Did the parents of the bride and groom have any objections? There should be no parties with objections.

If, after three announcements at church, no one raised any objections, only then could the marriage proceed to the civil registry. After the marriage at the Civil Registry Office was done, only then could they go to the church to be wed. When I was the district head of South Yapen, I also doubled as the extraordinary registrar. The Chinese and Dutch were that way too. Everyone was subject to the regulations. But if you did not marry there and wanted to marry in Hollandia, you could go for a break to Hollandia and get married there.

It might turn out that the woman was already married, that she had been kidnapped or stolen by another. What happened next depended on her husband and family: if they wanted to press charges with the police, then the police would bring them to the Landschapsrechtbank (Regional Court), where the Wetboek van Strafrecht (Penal Code) or Burgerlijk Wetboek (Civil Code) was in effect. But if the parents did not complain to the police, they settled the case themselves according to adat law.

According to adat law, they had to pay a fine, and the case was settled. There was no indictment, such as that the person had to be beaten this many times, or punished like this. Once the fine was paid, the case was closed. The fine took the form of property. These are some aspects of working as an administrator in the Dutch period.

\section{THE UNTEA TRANSITION}

At the time of the transition of the government from the Dutch to the United Nations Temporary Executive Authority (UNTEA), I was transferred from the district of Boven-Tor to Sentani to replace the district head, Mr. J.D. Donker. Yes, it was a real surprise to see the UN come in. But we just took it easy. We watched the UN enter with Gurka troops from Pakistan - the UN forces seconded to provide security in Papua. When they arrived the situation was secure. Only after the UN came in, then the Indonesian military forces arrived. After Indonesia came in with its forces, well, this, in our view, was difficult. They were serving here, and 
some were honorary workers, but when they wanted to go home, they bought up all the goods left by the Dutch in the shops. The stores looked more and more empty. Fabrics, tape recorders, all kinds of goods got sold out. We saw that, oh, this was dangerous, eventually we were no longer getting our share. So we were disappointed indeed! Everyone, the whole nation of Papua, was truly frustrated. After the UN surrendered governance to Indonesia, this brought even more bitterness for us Papuans!

All the more so for those of us who were government employees, former employees of the Dutch. After they came in, then made a decree (surat keputusan in the Indonesian language) yes, that we were demoted. Our salary scales also went down; it was a hassle for us. It was incomparable to the Dutch period. Later, from 1965 onward until 1969 we had difficulty shopping to meet our needs. Sugar was hard to come by, rice was hard to come by, finding towels was hard, finding clothing was hard. As for the shops left behind by the Dutch, that is, the Chinese stores that had operated in the Dutch period, none of them stayed open. All of them were shut down because they had no goods to sell. There were no imported goods. Everything society needed came to a halt. It was also difficult to buy cloth for women's clothes. We had to explain this to the public since this was also the responsibility of a government official.

It took quite a long time for the situation to improve. Although not that many goods came in, the prices kept rising. And there were few goods, so whoever moved fast, could buy, whoever moved slowly got nothing. Whereas the needs were pressing. Many Papuans needed things. But if they were late, they could not get any. All goods were imported through Irian Bhakti, the former Nieuw-Guinea Import \& Export Maatschappij (NIGIMIJ). There was only one company, that is all.

And I should explain here that in Dutch times, NIGIMIJ was a company that imported goods into Papua. And the prices were set by the Department of Economics. The Chinese could not toy with the prices. After Indonesia came in they toyed with the prices of goods, because this shop here set a different price, that store there would set yet another price. There were no announcements through the Department of Economics.

Nowadays, it is really properly organized. But if we compare the prices of goods in Dutch times with the prices of goods later on, there is a difference. We can see the vending stalls from here. Previously, there 
was only the Tjoh store. Now, this store appears, that store appears, that stall, this stall. And their prices are far different from each other, and far more expensive. Ah, these are difference that we Papuans have experienced and felt.

\section{REGIONAL COUNCILS}

After the Dutch left, all the councils were dissolved from 1963 and 1964 onwards. The Nieuw-Guinea Raad (New Guinea Council) and its membership were dissolved. Streekraad Dafonsoro, the Regional Council, also disappeared. No one was managing it any longer. Moreover, nobody knew the whereabouts of their property and equipment, such as trucks and rollers.

What I do know is that up until that time, the Nieuw-Guinea Raad still existed in Hollandia. There was a regional council, Streekraad Dafonsoro, here. And there was the role of the district head. The Regional Council required land, for plantations, which was processed with the land-leveling equipment owned by the council. There were regional councils back then in Hollandia and Teminabuan, as well as in Biak, Nabire, and Serui.

The Dafonsoro Regional Council endeavoured to ensure that community needs could be met. It provided opportunities to the local residents to open large-scale plantations. Then it helped out with ploughing tools to open the fields to be planted. Payment to the council for the ploughing machinery was calculated starting from the time it left the parking lot to the time it was brought back to the parking lot - the total number of hours. This was the leasing system the council used. The same applied to trucks. If you had to lease one, you could just go and lease it. All the money was paid to the Dafonsoro treasurer. So, during the time I served in Sentani, the council was active. After I moved, I noted that eventually, the government was no longer helping, and it disappeared.

After the transfer of government with the UN, everything fell silent, the council did not receive a subsidy anymore. The council did not have its own budget. So everything stopped, even though if the government had continued to help at that time, the Sentani area would be more advanced today. 
As for democracy, well, after Indonesia took over, everything constantly being touted on the radio, all things democratic, ceased to exist in the Indonesian period. It was hard for us! We were under pressure. If we talked about democracy, we were branded as OPM, members of the Free Papua Movement. This is what bothered us! As Bapak Imbiri recently said: 'Whenever voices were raised even a bit, they said you were OPM; whatever it was you said, OPM.' That really saddened us Papuans!

Regarding the determination of our stance: in accordance with the New York agreement, an election was to take place in 1969. Indonesia designated the People's Consultative Council for the vote: to enter Indonesia or seek independence. Throughout this whole process not a single civil servant was functioning! Everything was arranged by the Indonesians themselves. Not a single Papuan played a role in its stewardship. In fact, all the people who were selected, so many people per district, were people who were certain to be pro white and red. They were pre-determined from the start! Whereas people should have been registered in each district - for example, in Nabire, all adult citizens who were entitled to vote should have been registered there first. There was none of that!

Yes, so none of us knew a thing. At the time I was the deputy regent in Serui. We had no idea anyone had left. Because of that, it was an election that was held with people appointed by Jakarta. They asked only for the information: was the person pro white and red or not? Whoever was 'pro', his name was noted, and he later got summoned and sent to Biak. That is why we said the Act of Fee Choice (1969) was legally defective! To this day the charge still stands: legally defective!

According to the National Party, it should have been implemented by registering all Papuans, then everyone would vote using a polling card, which each person would fill out: to be independent or join Indonesia. Not at all! We did not know! Those who participated came to only 1,026 people.

\section{ELECTIONS IN THE DUTCH ERA}

Civil servants did not take part in the election process, just as in the time when the New Guinea Council and the regional councils, such as 
Streekraad Dafonsoro, were formed. But during the elections of voters' representatives for the New Guinea Council, the civil servants really did perform a function. At that time I was a seconded administrator. I was ordered by HPB Lagerberg of Genyem to go down to Demta to register all the residents who were 18 years and over to choose voters' representatives who would then select the members of the New Guinea Council. That is what I know, that the administration took part in the process. In the Indonesian period that did not happen.

Yes, we registered those who were 18 years of age and up and already had a family. We registered people, starting from Demta district, village by village, up to kampung Tarfia, the last village of the district. I compiled the list and submitted it to my friend, Andreas Karma, the district head of Demta; his staff typed it up and I received one copy (a carbon copy) for HPB Lagerberg. And he sent a copy directly to Hollandia for the New Guinea Council.

At that time, it was good, a true democracy. Because a photo of each candidate was posted everywhere to let people know who the candidates were. The photos were posted everywhere, in front of shops, in crowded places, in front of movie theatres. In the case of the villages, the photos were distributed through the district head. He distributed the photos, promoting the candidates objectively, impartially. That was the duty of the administrators in the time of the Dutch, but during the Indonesian Act of Free Choice, we were not functional.

In that time the ones that made nominations were the political parties, for instance, the Partai Nasional (Parna, National Party), Democratische Volks Partij (DVP, Democratic People's Party), and others that nominated candidates. All the parties were involved in the nomination of the members of the New Guinea Council. And each region also put forward their own candidates, particularly in areas where there were no political parties. So the candidates came from two groups, but according to the districtenstelsel (district representation system), and the nominations were direct.

The election of the members of the New Guinea Council took place following a 'one man, one vote system'. Take, for example, Mr. J.O. de Rijke, a lawyer in Hollandia. He was a Dutchman who was a candidate and was also elected. I still remember the other candidates too, such as Reverend Hermanus Mori Muzendi. He did not succeed in being elected, because Mr. de Rijke got more votes. It might seem strange for 
Papuans not to choose a Papuan but a Dutchman. Yet it happened. So be it, Reverend Hermanus Mori-Muzendi made a gracious retreat. It was a matter of trust, so Mori Muzendi (the Papuan) stepped down, and de Rijke (the Dutchman) stepped up. He was elected because he had won people's trust. Not like today.

Finally, reflecting on the Dutch period, my interactions with my fellow administrative officers were just fine. We were all bachelors. When I served in Genyem, I too was single and we were all very good friends. Among others there were Ligtvoet, den Hoed, Donker, and many more, but I forget their names. We drank beer together. We went deer hunting using shotguns, shot them, took them home, cut them up, cooked and ate them together in the pasanggrahan (guest house). We were really close friends. That was our life in Genyem. There were also some Indo-Dutch people who brought trucks (to work on constructing the roads); we lived together as friends. We all got together and worked together. With my Dutch superiors such as the HPBs, relations were fine too. No one offended us Papuans. In places where I worked as a clerk at that time, all the HPBs treated us kindly. When the time came to submit proposals for salary increases, the proposals were sent to the resident. Then we received a decree for a salary increase. Or when it came to the point of proposing a promotion, we were promoted. So everything went well! 